\title{
Deciding Staged Battles of the Past: On the Rhetorics of Olaf Müller's Historical Philosophy of Science
}

\author{
Michael Hampe ${ }^{1}$
}

Published online: 24 April 2018

(C) The Author(s) 2018

\begin{abstract}
Since Plato's massive critique of the Sophists rhetoric's ill repute runs through the history of western philosophy denunciating methods of rhetoric as in large part dishonest persuasion strategies which are at most marginally interested in dealing with truths. This judgement falls way too short insofar as it distorts the historically grown stock labeled "rhetoric" not only in the Aristotelian work. With reference to Olaf Müller's philosophical book (Mehr Licht: Goethe mit Newton im Streit um die Farben, S. Fischer, Frankfurt am Main, 2015) addressing the "controversy" between Goethe and Newton about the nature of light, I will study the different rhetorical models and methods used by Newton and Goethe and also Müller himself. It becomes apparent that even works attempting to decide who was right in the long run do far more than trying to evoke true "representations" of facts or truths in the reader. The specific use of language patterns provides deeper insight into an author's mindset towards the subject area discussed in his work and generally speaking the investigation of the rhetoric of science and philosophy leads to a better understanding of different epistemic cultures both in philosophy and science.
\end{abstract}

Keywords Rhetorics of science and philosophy · Narrative knowledge $\cdot$ Philosophy as referee

\section{Rhetorics of Philosophy and Science}

Goethe and Newton had, unlike Descartes and Hobbes or Cassirer and Heidegger, no debate with each other. Goethe criticized Newton 90 years after his death. Olaf Müller has written a book (Müller 2015) in which he stages a debate between Goethe and Newton. This stage-setting is a rhetorical device that is firstly characteristic and expressive of the

Michael Hampe

hampe@phil.ges.ethz.ch

1 Chair for Theoretical Philosophy, ETH Zuerich, Clausiusstrasse 49, CLW C 2, 8092 Zurich, Switzerland 
specific philosophical character of the book and that is secondly important for the lines of argument at least in the first three parts of the book. This essay is about the rhetoric of Müller's book and about aspects of Newton's and Goethe's rhetoric in their optical writings. Since Müller's book is a philosophical one about science I will consider both the rhetoric of philosophy and the rhetoric of science. I will not argue against any theses of Müller's book, but will try to understand why it has the form it has and especially why it differs so significantly from books in German studies or the history of science that deal with the same authors.

"Rhetoric" is a word with a bad reputation in philosophy. Persuading and convincing are considered to be two opposed types of belief-formation, belief-transmission and belieffixation, one of which is supposedly dishonest and the other fair-minded. Rhetoric deals allegedly with unfair persuasion; science and philosophy on the other hand are considered to be ways of conveying the truth in a fair and transparent way. To speak of the rhetoric of science and philosophy seems therefore to imply that in science and philosophy dishonest strategies of belief formation are used at least in a concealed way, and that science and philosophy have a wrong picture of their own epistemic practices.

This way of looking at things may stem from the opposition Plato constructed between the philosophers and the sophists (Plato 1977a, b), the masters of rhetoric, whom he caricatured as just teaching the tricks to convince people of something by speaking effectively without caring about the truth of what they say, i.e. persuading people of something by a manner of speech for which it does not matter if it represents the facts or not.

But if we look at Aristotle's Art of Rhetoric (Aristotle 1975) this is much too simple a picture. Aristotle considers rhetoric and dialectic as methods "to criticize or uphold an argument, to defend oneself... or accuse" others argumentatively, methods that are used by a "majority of the people" (Aristotle 1975, 2-3), not only by those who search for knowledge in a scientific way but also by politicians and lawyers. The consideration of proofs by syllogisms and of incomplete arguments like enthymemes (short or incomplete arguments that do not state their premises) is part of rhetoric in this Aristotelian sense.

In this picture valid arguments and true representations of how things are are one way of defending oneself or of accusing somebody else of being wrong. Thus rhetoric is about the effectiveness of language: what language does to those who listen or read a speech or a text and also to those who use language by saying or writing something (cf. Hetzel 2011). The truth of a statement or its value as a representation is one factor among many others in what a statement does to its recipient. It was no original insight of Searle's in his theory of speech acts to see that language does not just have a representational function, that people do many more things with words. ${ }^{1}$ This insight can already be found in the ancient treatises on rhetoric from Aristotle to Cicero, from Tacitus to Augustine-treatises that had been forgotten in the modern philosophy of language, probably because of the bad reputation rhetoric had as a discipline in philosophy, as Andreas Hetzel rightly observes (Aristotle 1975; Cicero 1948; Tacitus 1914; Augustine 1975; Hetzel 2011, 40).

In all sciences there are different methods of convincing a reader. Arguments are not just presented naked but used in different ways and contexts (Toulmin 1958, 36-38), and what is considered a good or bad argument and appropriate or inappropriate evidence differs from science to science and from context to context. Furthermore, in all sciences

\footnotetext{
${ }^{1}$ Hetzel shows that Searle's theory of speech-acts could only be conceived as an innovation in the philosophy of language because the tradition of classical rhetoric was no longer known to philosophy. Cf. Hetzel (2011, 40).
} 
metaphors and analogies, classical rhetorical devices, are used not only in order to make a hypothesis imaginable, but also to guide reasoning (Blumenberg 1960; Hesse 1966; Baake 2003): think of electromagnetic energy travelling in waves, electricity in a conductor as a current, the brain as a computer, or, coming to the metaphor that is important for us: light coming in thin rays, like water out of a hosepipe.

I do not claim that the representational function of individual statements is irrelevant in science or philosophy and that the context in which it is placed and the metaphors, analogies etc. used in it are everything. I follow Philip Kitcher's middle view on this topic that rhetoric is not everything in forming beliefs, but that it matters a lot, especially if one wants to understand the different cultures of knowledge in the different sciences (Kitcher 1995).

For the rhetoric of philosophy one can say that the context in which most philosophical statements are placed is that of an everlasting dispute (Flasch 2006; Berthold 2011). Often juridical metaphors are used in order to prepare this context, as we will see later. (Another important metaphor often used to set the stage for philosophical reasoning is a medical one: philosophy as a cure of the mind, as medicina mentis. (Tschirnhaus $1963^{2}$ ) Philosophy is rarely just told or stated (although books like Spinoza's Ethics or Wittgenstein's Tractatus seem to do just that). Arguments in philosophy are usually directed against someone: a philosophical contemporary or predecessor or an opponent in the sciences. This will become important for understanding the rhetoric of Müller's book. One has to look at the different philosophical schools (such as analytical, continental or pragmatist) to see how arguments are used in a philosophical dispute and what counts as a good argument. Questioning e.g. the practical relevance of a distinction or an argument, say about the ontology of objects in the ordinary world (Sattig 2015), can be a very important move in a pragmatist context, but it may not be a "good move" in a purely analytical or continental one.

Unlike the rhetoric of philosophy, the rhetoric of science is nowadays a quite wellestablished variety of philosophy and sociology of science (cf. Hesse 1966; Prelli 1989; Gross 1990; Harris 1997; Fahnestock 1999; Baake 2003). ${ }^{3}$ Michael Böhler's investigations into the differences between narrative and non-narrative ways of knowledge, which he has applied to Goethe's scientific writings-interpreting them as an example of narrative knowing — are a brilliant example of a study of the rhetoric of science (Böhler 2015). (We will come back to Böhler's essay later.) The rhetoric of philosophy and of the philosophy of science on the other hand is not so well established. But if one considers rhetoric of science as an investigation into the means by which different sciences produce their evidence, it should also be possible to study the means by which philosophy and the philosophy of science bring about their evidence and the ways in which they enter into and behave in disputes. There do exist some reflections about the literary form and rhetoric of philosophical texts (Schildknecht 1990; Schildknecht and Gabriel 1990). But philosophers

\footnotetext{
${ }^{2}$ On the rhetorical settings of philosophical reasonings cf. Hampe (2007).

3 The difference between a philosophy of science that tries to engage itself in debates about the truth of scientific theories and one that focuses on rhetorical analysis may have today institutional and political implications that relate to the competition for money and attention between analytical and non-analytical thinking about science. But since a clear description of analytical philosophy of science and its history and a demarcation of this tradition from the aims and histories of Hermeneutical and Phenomenological philosophy of science and enterprises like Historical Epistemology and Science and Technology Studies would be a task of its own, I must refrain from discussing these institutional and political implications. I consider therefore-in an idealizing way-present-day rhetorics of science as a continuation or return to the ancient and renaissance tradition, similar to the perspective of Stephen Toulmin (2001, 12; 1990, 30ff.).
} 
of science are usually unconscious of the fact that they produce texts of a certain form (cf. Nordmann 2011, 368).

Therefore, I want to investigate the means by which Olaf Müller, as a philosopher of science, treats evidence and behaves rhetorically in a dispute he has set up in order to study the history of optics. And I will look at the way Newton and Goethe try to convince their readers in their optical papers. Thus this paper has two aims. I will pursue a metaphilosophical task by looking at the rhetoric of Müller's book. And I will do a bit of rhetoric of science by considering Newton's and Goethe's own writings.

\section{Standardizing Goethe and Newton}

Müller presupposes that Goethe and Newton were pursuing the same science: the empirical science of optics. By putting them into one and the same box of empirical or experimental science he wants to make it possible for Goethe's criticism of Newton to be reconstructed in the scenario of a debate or fight. If A plays hockey and B chess, there cannot be a competition between them. But what Müller wants to decide is the competition between Goethe and Newton. He is a philosopher who thinks like many other of his brand in terms of debates: realism against idealism, externalism against internalism, empiricism against rationalism and so on. One might think that this is characteristic for the rhetorics of contemporary analytic philosophy. But that would be a historical mistake. "Rationalism" and "Scepticism" and "Dogmatism" and "Criticism" are "pre-analytic" schools of philosophy that were confronted with each other in staged battles already in the eighteenth century. ${ }^{4}$ And the non-analytic philosopher Heidegger engaged in fierce battles against the whole metaphysical tradition and against the Neo-Kantianism and humanism of this time. ${ }^{5}$ Other scholars who looked at Newton and Goethe tried to show that there was a fundamental difference separating Newton from Goethe, that Newton tried to explain in a causal way where colours come from and that Goethe was more of a phenomenologist, interested in describing the appearance and relations of colours, or as Michael Böhler claims, that Goethe was producing narrative knowing, but did not want to produce scientific knowledge, that he wanted to tell a story about the experiences of colours, which Newton did not want to do (Böhler 2015, 62). Böhler quotes the following passage from Goethe in this context:

We cannot truly and honestly rejoice in the merits of our own time if we do not know how to appreciate the merits of the past. But it was not possible to write or even to prepare a history of colour theory as long as the Newtonian theory held sway. For no aristocratic conceit has ever looked down with such intolerable presumption upon those who did not belong to its guild as the Newtonian school has always done in its denial of validity to all that was achieved before itself and was being achieved alongside it. (Goethe, Zur Farbenlehre, here quoted from (Böhler 2015, 61).

\footnotetext{
${ }^{4}$ Kant draws a line between theoretical-dogmatic speculation or Rationalism and Scepticism (Kant 1981, 615). His transcendental philosophy appears as a solution to the debate between Leibnizian speculation and Humean scepticism. A debate between dogmatism and criticism is construed by Schelling (1982).

5 Heidegger thought that since Plato and Aristotle philosophical discourse on "being" was on the wrong track and had to be destroyed and replaced by what he called "Fundamentalontologie" (Heidegger 1985, Sect. 1). For Heidegger's fights with Neo-Kantianism, logical positivism and humanism cf. Friedmann (2000).
} 
According to Böhler Goethe is an exponent of a "narrative knowledge culture" that was disappearing in his time, in which the "narrative of the genesis and handing down" of knowledge is a necessary part of any knowledge. There is no unhistorical knowledge in such a culture. Newton on the other hand, like Descartes, is an exponent of a non-narrative culture of knowledge or of the new mathematical-experimental science. Both of them, Descartes and Newton, want to get rid of historical knowledge. It is a burden for them, at least on the surface of their writings, especially the Aristotelian tradition in natural philosophy operating with forms and teleological arguments and not using the mathematical symbolism. This is the reason why they represent their knowledge in the mos geometricus by stating definitions, propositions, and axioms and why they produce proofs in a tenseless setting, as Newton does in his "Opticks". Narratives are uninteresting here. Supposedly tenseless truths, like the ones in mathematics, are what count. Thus the mathematical form, the imitation of Euclid's geometry in Newton's (and Spinoza's and sometimes in Descartes') writings is not just a "natural" way of stating arguments transparently. ${ }^{6}$ It is a rhetorical move: By using this form, the authors state implicitly that they do not want to tell stories anymore, especially not stories about their supposedly great predecessors and the debates they had. They want to "reboot" thinking. The insights they intend to produce after this rebooting shall last. They are not just a contribution to an ongoing story, but an endpoint as sure and unshakeable as the insights of mathematics.

Müller does not discuss these differences between conceptions of knowledge. That Goethe writes reports about his experiences with colours and that these reports look so different from Newton's drawings of the experimental settings is not important to him. He wants to decide the question "Who is right?" (Müller 2015, 38) To try to interpret Goethe's morphological knowledge as a different kind of science from Newton's is in his eyes an attempt to avoid this tough question, it is a soft strategy of getting around this conflict and according to Müller is neither fair to Newton nor to Goethe (Müller 2015, 220). For him Goethe and Newton produce different proofs. The fight he stages between them is a "proof-theoretical one" relating to the question whether darkness ("Finsternis") can be treated as an "optical causal factor" (Müller 2015, 226). Proofs are indeed important in Newton's Opticks. In Goethe's theory of colour the geometrical method of presenting knowledge is not used. In the didactic part of his theory of colour Goethe produces 920 aphorisms that report experiences he had in experiments, that give statements about the nature of light and colour, and that ask the readers to make certain observations themselves.

It is well known that Goethe's "morphological method" is intended to produce evidence by creating continuous lines ("stetige Folgen") of particular phenomena in order to trigger a "pure phenomenon" (Goethe 1958a, 37). One can speculate whether the aphoristic representation is the rhetorical way in which Goethe (and Wittgenstein (2009) follows him in this in his Philosophical Investigations (cf. Schulte 1990)) tries to present these lines of phenomena to the reader, making it more likely that a certain intuition may take hold of the reader's mind.

Arguing more geometrico or producing lines of aphorisms can thus be taken as different rhetorical ways to refer to two different ways of thinking: (1) a deductive way of thinking, in which the mind grasps certain more or less self-evident premises and some rules of inference and moves from there on to conclusions, and (2) a comparative or analogical way of thinking, in which the mind moves from one phenomenon to the next one, from one

6 The relevance of Descartes' Geometrie and Dioptrique for Newton is reported by Shapiro (1984, 7f.) in his "Introduction" to The Optical Papers of Isaac Newton. 
description to the next one until a kind of family resemblance or master phenomenon is formed.

Goethe seems to think of every particular experience (experimentally produced or not) as being situated in a kind of "phenomenological totality", such that its relevance only becomes evident if it is placed in the right spot in this context, the way we understand what a piece from a puzzle shows by putting it in the right place of the whole picture. Goethe's criticism of Newton relates to these contexts which Newton supposedly does not see or cannot see, because he puts all phenomena of light into the wrong context from the start by treating light as something that is made up out of rays in order to be able to use geometrical lines in his explanations. It is a constant danger, according to Goethe, especially arising in a "strong mind" like Newton's, not to wait long enough to detect the right context in which a phenomenon is to be placed in order to understand it, instead forcing a phenomenon "despotically" into some made-up context that suits one's own intellectual preferences and dispositions. Like in the passage quoted above from Böhler, where Goethe compares Newton's school to an aristocrat who looks down on others, he uses the metaphor of despotism in order to characterize a hasty treatment of data: flattering data, data that fit a prejudice, are favored, all other data are suppressed. ${ }^{7}$ Collecting as many data as possible, even if they do not seem to fit to each other, and waiting for the production of a theory as long as possible is a methodological principle of Goethe's; a principle that might have given him the reputation of being "just" a phenomenologist, interested in the collection and description but not in the explanation of data.

Müller certainly knows about these methodological differences but they are irrelevant for his view of the "quarrel" between Goethe and Newton (Müller 2015, 39f.). In order to treat Goethe and Newton as two "heroes", who always wanted to be "winners" and who do not compromise, do not make deals (cf. Müller 2015, 27) he has to standardize his picture and to make Goethe into somebody who had a "theorem" for which he wanted to argue by pointing to experiments. Although Müller mentions Goethe's denial of the possibility of proving or refuting a theory by an experiment (cf. Müller 2015, 129), he relates this not to Goethe's holistic view of the organization of experiences and his aversion to explanatory theories in general, but to Quine's idea of underdetermination. Müller has to assimilate Goethe's view of an empirical science to the picture of an experimental science that is perhaps akin to Newton's own view of science, or probably more akin to a picture that is drawn by Müller himself and that is neither really Newton's nor Goethe's view of the proper empirical science, but the one that twentieth century philosophy of science uses. The rhetorical setting of Müller's book puts contemporary philosophy of science in a very prominent position: for it is this philosophy that allows him to play the role of a judge in the quarrel he invented. The important alternative for Müller in this context is: "experimentum crucis or underdetermination of theory by experiment" (Müller 2015, chapter IV.1). Goethe is the "hero" who "wins" in this contest, because he supposedly anticipated Quine's underdetermination theorem.

But the insight that "deductively there is no path from experiment and observation to theory, neither in opticks nor anywhere else" (Müller 2015, 323) puts Goethe's and Newton's views of what an experiment and an experience means in a historically

\footnotetext{
7 See Goethe (1958b, 30): “...der Mensch erfreut sich nur einer Sache, insofern er sich dieselbe vorstellt, sie muss in seine Sinnesart passen... daher die Neigung zu Hypothesen, Theorien, Terminologien und Systemen... Man wird bemerken können, daß ein guter Kopf nur desto mehr Kunst anwendet, je weniger Data vor ihm liegen, daß er, gleichsam seine Herrschaft zu zeigen, selbst aus den vorliegenden Datis nur wenige Günstlinge herauswählt, die ihm schmeicheln ... einem despotischen Hofe ähnlich.”
} 
oversimplified manner in the same box-oversimplified at least if one takes into account the existing works (besides Böhler's) on the methodological differences between Goethe and Newton that consider Goethe's attack onto Newton e.g. as a theological one or as one that arises from a peculiar interpretation of Bacon's empiricism. ${ }^{8}$

Müller also does not analyze in what sense the geometrical method and the idea of proof in Newton is applicable to the experimental subject Newton is dealing with, i.e. in what sense one can stick to the geometrical form of argumentation when moving from geometry to optics. Newton gives "Proofs by Experiments" in his "Opticks". (cf. Newton 1931, 20) But it is obvious that these proofs, although they are presented in the same way as the proofs in a geometrical treatise, cannot be of the same nature as proofs in geometry (of which there are many different types (cf. Heintz 2000)). In geometry the drawing can give or $b e$ itself the proof, or understanding the drawing in Euclid's Elements can be considered understanding his proofs. In Newton's Opticks the drawings are just reports about or instructions for the execution of experiments, since one cannot put the experiments themselves into a book. Thus the drawings cannot have the same demonstrative power that they have in Euclid. Thus Newton is only in a superficial way arguing more geometrico.

It is Müller's rhetorical role as a philosophical judge over a debate that forces him in most parts of his book to present Goethe and Newton as authors who only differ in their optical theories and who both try in a similar way to prove their theories by experiments. The rhetorics of Müller's book suggests that Goethe and Newton cross swords by exchanging experiments. In three quarters of his book Müller sets up this rhetorical setting according to which one could decide which of the two, Goethe or Newton, has the better experiment as the "sharper weapon" in his hands in order to prove his theory (Müller 2015, 34 , he also writes about the "sharpest experiment", i.e. directly identifying weapons with experiments on p. 31). At the end Müller shifts his focus from theory and experiment to epistemology or philosophy of science, trying to show that Goethe has the more advanced philosophy of science epistemology and therefore "wins" over Newton, because he anticipated empirical underdetermination, which shows that an experimentum crucis in Newton's sense is impossible. But for Müller it has to be a fight and a tough decision.

\section{The Martial Tone}

This rhetorical setting of Müller's book-that a debate has to be decided-is the reason why the micro-rhetoric of Müller's book is continuously militant. Its martial tone is already established in Müller's report of the history of his book. Originally Müller $(2015,11)$ tells us he was planning "to have a go" at Goethe's "Farbenlehre" ("vorknöpfen"). His first motif was to deal with Goethe's optics in order to knock over Goethe's theory of colours once and for all by the means of modern philosophy of science, which had not been done so far. Thus he began his reading of Goethe's writing on natural phenomena not as a hermeneutical philosopher who recognizes the principle of charity before he turns to the historical setting of the ideas and propositions, assuming that they might be true in order to understand them better. He took the opposite attitude: Müller suspected that Goethe's ideas about optics were nonsense, and he studied them carefully with the intention of proving this assumption. He wanted to shut up the Goetheans who still believed that their master

\footnotetext{
8 Albrecht Schöne $(1987,85)$ describes Goethe's critique of Newton as a theological one. Nisbet (1972, 23-47) discusses Goethe's empiricism against the background of his ambivalent relation to Bacon, from whom he got the idea of premature induction.
} 
had found something of scientific value in his optical studies. That is certainly a very different attitude that leads to a different way of speaking about "your" author than the one a specialist in German studies or the history of science would take. No historian of literature or science wants to destroy his or her "object" in such a way. It is the very special attitude of a certain type of philosophy to turn to history with a destructive intention: to show e.g. that Hegel was nuts, that James contradicts himself, that Derrida is balderdash and so on. This destructive intention is not typical to a special philosophical school like analytical philosophy of science or Oxford style philosophy of language, it can also be found in Nietzsche (1955), Marx (1978), Heidegger or Adorno (1973). Thus Müller's attitude and the aggressive rhetoric that result from it may have a long philosophical tradition they are not at all typical for scholars in German studies who are interested in Goethe or even in Goethe's criticism of Newton (and who Müller ridicules en passant_- "tandaradei"). Müller's attitude and rhetoric are typical for a critical philosophy that believes that today we have "sharper weapons" for reasoning, better tools of thought that can save us from the foolishness of our intellectual predecessors. Only in philosophy, not in the history of science or in literary studies and not in science itself, is it possible to be interested in showing that an author of a more than 200-year-old text was entirely wrong and to feel obliged to make this public in order to rebut possible followers, because only in philosophy do we see the phenomenon of followers who somehow orient their thinking through very old texts, as the Aristotelians, Kantians or Hegelians in our present times do. (This setting of followers and their attackers is much more similar to political and religious conflicts than to scientific ones.) Thus Müller intended at first to "destroy" Goethe's theory of colour in order to show that there is no intellectual point in trying to be a "Goethean" in the natural sciences, just as somebody who has read Wittgenstein's Philosophical Investigations or Quine's Word and Object might turn "against” Plato's philosophy of ideas in order to show that Platonism is a non-starter in the theory of meaning.

Although Müller was in his own assessment not successful in his original project, and had to give Goethe the credit of anticipating Quine's underdetermination thesis (in Müller's book Part IV), he did not have to change the rhetorics of his book. The rhetorical setting of the book is still determined by his original intention to wrestle down Goethe, although during the fight Goethe proved to Müller to be stronger than he thought.

This is where the book got its bellicose storyline and tone from. Part of this storyline and the rhetoric it employs (besides weapons, as on p. 34, it also refers to chess moves e.g. on p. 39) might be due to the fact that the book is aimed at a wider audience, not only at academic historians of science and people in German studies. The book, as Müller might have thought, may be a more fascinating read if it's about battles and decisions. But it seems to me that Müller has also put his philosophical heart into this work and that the rhetoric of the book is not artificially made up for the wider readership. The rhetoric of this book mirrors, I assume, how Müller thinks as a philosopher about Newton and Goethe: They are two warriors for him with more or less effective experimental weapons, and he, Müller, is the referee who decides who has fought better and deserves the laurel. Thinking in terms of debates and fights and seeing philosophy as the referee may be a natural way of thinking, say for people trained at Oxford in philosophy. But it certainly is not the obvious and only way of thinking historically about Goethe or about Goethe and Newton, since Newton and Goethe could never have exchanged arguments, say in the form of letters like Leibniz and Newton did in the Leibniz-Clarke debate. Neither scholars who are interested in the historical truth about Newton and Goethe nor contemporary physicists who are interested in the truths about light and colour could have written the book Müller has written. In its tendency to think about the past in terms of fights, to be obsessed with 
winning and domination, it is a genuine instance of a certain type of philosophy, a philosophy that is much more akin to sophistry and the matadors of rhetoric than it might think itself: a philosophy that is not only interested in the truth (like scientists), but that is motivated by identifying winners of debates or by being able to decide debates as an umpire. Ever since Kant used the metaphor of a law-court of reason ("Gerichtshof der Vernunft" (Kant 1956, B779)) and placed philosophy in the position of a judge at this court of law, the self-understanding of this subject has been guided by the idea that it has the power to decide debates about knowledge-claims. In the philosophy of science it was especially Popper's transformation of this law metaphor into what he called the demarcation problem, according to which it is the job of philosophy to decide what is a proper science and what a pseudo-science (identifying psychoanalysis and Marxism as pseudosciences), that shaped the attitude of many philosophers of science (Popper 1963, 37). Articles in Nature or Science are usually not about debates or decisions about debates. They state what has been found in measurements or what theoretical conclusions we have to draw from some empirical data. Empirical science might be competitive (who discovered it first? who got more money for his research?). But the argumentative fight or bossiness ("Rechthaberei") is not at the heart of scientific thought and rhetoric, nor is it in the historical disciplines.

Here another pattern enters the storyline of Müller's book. Müller does not just act as the referee over the fight he sets up between Goethe and Newton. He also conducted many optical experiments himself, met with people who did such experiments and like Goethe asked other people (and the reader) to perform them. In doing this he wants to challenge the self-sufficiency of present day optical science. Thus he not only wants to stress the Quinean thesis that empirical science in general and optical science as well is underdetermined by its empirical findings. He also wants to show that Goethe's view of light, according to which darkness might be a causal factor in the production of colours, is stillbecause of the underdetermination - a possible way of looking at things. He insists that Goethe's critique of Newton "has lost none of its bite" ("nichts von ihrem Biss verloren") even for contemporary optics (Müller 2015, 227). In his own mode of speaking one could say that he opens up "another front" in his book beside the front between Newton and Goethe, i.e. one between the empirical philosophy about colours he started in order to understand Goethe and present day optical science. He does not argue against present day science as a devoted fan of Goethe's way of looking at the world. Müller is not a "Goethean". It is more that when he finds that he is unable to destroy Goethe's supposed assumptions in optical science he also discovers that even contemporary optical science has "no weapons" to defeat them.

Contemporary philosophy rarely enters in debates with the empirical sciences. The recent criticism by philosophy of the neurosciences was targeting the supposedly rickety conceptual framework of this science and intended to resolve a draw in the interpretation of empirical data (Bennett and Hacker 2003). Neuroscientists, so Bennett and Hacker (2003) argue, talk in a metaphorical way about the brain; if they say e.g. that a certain part of the brain sees, hears or feels something. It is according to them the whole person who does such things. The problem with this argument is that history of science shows that metaphors become concepts (i.e. electric current, mathematical knots, electro-magnetic waves, etc.). Nobody considers today the phrase "the current of electricity" as a metaphor anymore. If people continue to talk about brain-regions as seeing or hearing something or as thinking about something this way of talking (and looking at things) may become literal in the future. Thus philosophers who want to be more than guardians of the old ways of speaking have good reason not to start disputes with the sciences themselves. The past 
shows that when they tried to interfere with the future development of empirical research or the outcome of experiments or with scientific neologisms it did not turn out well, because philosophy has no power about the conceptual development of empirical science. Think about Kant's assumption of biology's status as a science: that there will never be a Newton of the blade of grass (Kant 1968, 400) — did Watson and Crick (1953) and Turing (1952) and his followers in mathematical embryology not do this job in 1952/1953? Or consider the critique of atomism by positivism at the end of the nineteenth century (Mach 1904, 521; for Mach's position see also Wolters 1988). One could certainly argue that the results of Watson's and Crick's research about the structure of the DNA and the applicability of Turing's formalism onto the embryological tissue development are not really equivalent to Newton's laws. But nobody today would say (like Kant) that therefore biology is not a proper science, because it does not construct its concepts geometrically. Seeing the molecules from which genetic developments take place and having a formalism to calculate this development is as scientific as you can get biologists would say. Kant or philosophy in general has no copyright on the term "science" or any other scientific term (as much as Popper and some of his followers in the philosophy of science would have liked to).

Müller sees that contemporary physics of light with its theory of photons will not care about darkness as a causal factor (Müller 2015, 285f.). Nevertheless, he seems to me to be heroically optimistic that his view of Goethe's theory of colour and of Goethe's epistemology challenges not only the dead Newton(ians), but also contemporary optical physics. But will physicists care about the underdetermination of their classical optical theory by their experiments? Although I admire the empirical work he has done, and although physicists in this volume confirm it, I assume that he is too optimistic in this case. I expect that as little as neuro-scientists care about the (still) metaphorical character of their talk about areas of the brain so physicists will not care about the empirical underdetermination of their optical theory. As long as there is nothing grander theoretically for them in view they will not fiddle with what they found plausible and what fits with other parts of their science. But that is only a guess. I am not a physicist and have neither the competence nor the intention to give a prognosis about the impact Müller's book might have onto the actual development of optics.

Open Access This article is distributed under the terms of the Creative Commons Attribution 4.0 International License (http://creativecommons.org/licenses/by/4.0/), which permits unrestricted use, distribution, and reproduction in any medium, provided you give appropriate credit to the original author(s) and the source, provide a link to the Creative Commons license, and indicate if changes were made.

\section{References}

Adorno, T. W. (1973). Jargon der Eigentlichkeit. Zur deutschen Ideologie. In T. W. Adorno (Ed.), Gesammelte Schriften (Vol. 6). Frankfurt am Main: Suhrkamp.

Aristotle. (1975). The art of rhetoric (J. H. Freese, Trans.). In Aristotle. Twenty-Three Volumes (Vol. 22). Cambridge, MA: Harvard University Press.

Augustine. (1975). De dialectica. (Ed. by J. Pinborg) Dordrecht: D. Reidel Publishing.

Bake, K. (2003). Metaphor and knowledge: The challenges of writing science. New York: State University of New York Press.

Bennett, M. R., \& Hacker, P. M. S. (2003). Philosophical foundations of neuroscience. Malden: Blackwell Publishing.

Berthold, J. (2011). Kampfplatz endloser Streitigkeiten. Über die Geschichtlichkeit der Philosophie. Basel: Schwabe Verlag. 
Blumenberg, H. (1960). Paradigmen zu einer Metaphorologie. In Archiv für Begriffsgeschichte (Vol. 6). Bonn: Bouvier.

Böhler, M. (2015). 'Render innocuous the abstraction we fear': Johann Wolfgang Goethe in the epochal conflict between scientific knowledge and narrative knowing. In H. Blume, C. Leitgeb, \& M. Rösnner (Eds.), Narrated communities-Narrated realities. Narration as cognitive processing and cultural practice (pp. 51-68). Leiden: Brill Rodopi.

Cicero. (1948). On the orator (E. W. Suton \& H. Rackham, Trans.). Cambridge, MA: Harvard University Press.

Fahnestock, J. (1999). Rhetorical figures in science. New York: Oxford University Press.

Flasch, K. (2006). Kampfplätze der Philosophie. Frankfurt am Main: Klostermann.

Friedmann, M. (2000). A parting of ways. Carnap, Cassirer and Heidegger. Chicago: Open Court.

Goethe, J. W. V. (1958a). Erfahrung und Wissenschaft. In G. Ipsen (Ed.), Goethe-Sämtliche Werke, vol. 16, Naturwissenschaftliche Schriften I. Naturwissenschaftliche Schriften I. Leipzig: Insel Verlag.

Goethe, J. W. V. (1958b). Der Versuch als Vermittler von Objekt und Subjekt. In: G. Ipsen (Ed.), GoetheSämtliche Werke, vol. 16: Naturwissenschaftliche Schriften I. Leipzig: Insel Verlag.

Gross, A. G. (1990). The rhetoric of science. Cambridge, MA: Harvard University Press.

Hampe, M. (2007). Propheten, Richter, Ärzte, Narren: Eine Typologie von Philosophen und Intellektuellen. In M. Carrier \& J. Roggenhofer (Eds.), Wandel oder Niedergang? Die Rolle der Intellektuellen in der Wissensgesellschaft (pp. 33-54). Bielefeld: Transcript.

Harris, R. A. (Ed.). (1997). Landmark essays in the rhetorics of science. London: Routledge.

Heidegger, M. (1985). Sein und Zeit. Tübingen: Max Niemeyer Verlag.

Heintz, B. (2000). Die Innenwelt der Mathematik. Zur Kultur und Praxis einer beweisenden Disziplin. Wien: Springer.

Hesse, M. (1966). Models and analogies in science. Notre Dame: University of Notre Dame Press.

Hetzel, A. (2011). Die Wirksamkeit der Rede. Zur Aktualität klassischer Rhetorik für die moderne Sprachphilosophie. Bielefeld: Transcript.

Kant, I. (1956). Kritik der reinen Vernunft. Hamburg: Meiner Verlag.

Kant, I. (1968). Kritik der Urteilskraft, vol. 5 in Kant's Gesammelte Schriften. Berlin: De Gruyter.

Kant, I. (1981). Über die von der Königlichen Akademie der Wissenschaften zu Berlin für das Jahr 1791 ausgesetzte Preisfrage: Welches sind die wirklichen Fortschritte, die die Metaphysik seit Leibnizens und Wolffs Zeiten in Deutschland gemacht hat? In W. Weischedel (Ed.), vol. 5 in Immanuel Kant Werke in zehn Bänden. Darmstadt: Wissenschaftliche Buchgesellschaft.

Kitcher, P. (1995). The cognitive functions of scientific rhetoric. In H. Krips, J. E. McGuire, \& T. Melia (Eds.), Science, reason, and rhetoric (pp. 4-66). Pittsburgh, PA: University of Pittsburgh.

Mach, E. (1904). Die Mechanik in ihrer Entwicklung: historisch-kritisch dargestellt. Leipzig: Brockhaus.

Marx, K. (1978). Die deutsche Ideologie. Kritik der neuesten deutschen Philosophie in ihren Repräsentanten Feuerbach, B. Bauer und Stirner und des deutschen Sozialismus in seinen verschiedenen Propheten. In K. Marx \& F. Engels (Eds.), Werke (Vol. 3). Berlin: Dietz Verlag.

Müller, O. (2015). Mehr Licht: Goethe mit Newton im Streit um die Farben. Frankfurt am Main: S. Fischer.

Newton, I. (1931). Opticks, or a treatise of the reflections, refractions, inflections and colours of light. New York: Dover Publications.

Nietzsche, F. (1955). Götzendämmerung oder Wie man mit dem Hammer philosophiert. In K. Schlechta (Ed.), Friedrich Nietzsche, Werke in drei Bänden (Vol. 2). München: Hanser.

Nisbet, H. B. (1972). Goethe and the scientific tradition. London: Institute of Germanic Studies, University of London.

Nordmann, A. (2011). Philosophy of science (Ch. 31). In B. Clark \& M. Rossine (Eds.), Routledge companion to literature and science. London: Routledge.

Plato. (1977a). Protagoras (W. R. Lamb, Trans.) In Vol. 4 in Plato in Twelve Volumes. Cambridge, MA: Harvard University Press.

Plato. (1977b). The sophist. (H. R. Fowler, Trans.) In Vol. 7 in Plato in Twelve Volumes. Cambridge, MA: Harvard University Press.

Popper, K. (1963). Conjectures and refutations. The growth of scientific knowledge. London: Routledge and Kegan Paul.

Prelli, L. J. (1989). A rhetoric of science: Inventing scientific discourse. Columbia: University of South Carolina.

Sattig, T. B. (2015). The double lives of objects. An essay in the metaphysics of the ordinary world. Oxford: Oxford University Press.

Schelling, W. J. (1982). Philosophische Briefe über Dogmatismus und Kriticismus. In H. Buchner, W. G. Jacobs, \& A. Pieper (Eds.), Friedrich Wilhelm Schellings Werke (Vol. 3). Stuttgart: Frommann Holzboog. 
Schildknecht, C. (1990). Philosophische Masken. Studien zur literarischen Form der Philosophie bei Platon, Descartes, Wolff und Lichtenberg. Stuttgart: Metzler.

Schildknecht, C., \& Gabriel, G. (Eds.). (1990). Literarische Formen der Philosophie. Stuttgart: Metzler.

Schöne, A. (1987). Goethes Farbentheologie. München: Beck.

Schulte, J. (1990). Chor und Gesetz. Zur »morphologischen Methode« bei Goethe und Wittgenstein. In J. Schulte (Ed.) Chor und Gesetz-Wittgenstein im Kontext. Frankfurt am Main: Suhrkamp Taschenbuch Verlag.

Shapiro, A. E. (Ed.). (1984). The optical papers of Isaac Newton, Vol. 1: The optical lectures 1670-1672. Cambridge: Cambridge University Press.

Tacitus. (1914). Agricola. Germania. Dialogus. (M. Hutton \& W. Peterson, Trans.). Cambridge, MA: Harvard University Press.

Toulmin, S. (1958). The uses of argument. Cambridge: Cambridge University Press.

Toulmin, S. (1990). Cosmopolis. The hidden agenda of modernity. New York: The Free Press.

Toulmin, S. (2001). Return to reason. Cambridge, MA: Harvard University Press.

Tschirnhaus, E. W. V. (1963 [1687]). Medicina Mentis. Leipzig: Verlag Johann Ambrosius Barth.

Turing, A. (1952). The chemical basis of morphogenesis. Philosophical Transactions of the Royal Society of London. Series B, 237(641), 37-72.

Watson, J., \& Crick, F. (1953). A structure for deoxyribose nuclear acid. Nature, 171, 737-738.

Wittgenstein, L. (2009). Philosophical investigations (G. E. M. Anscombe, P. M. S. Hacker \& J. Schulte, Trans.). Chichester: Wiley-Blackwell.

Wolters, G. (1988). Atome und Relativität-Was meinte Mach. In R. Haller \& F. Stadler (Eds.), Ernst Mach-Werk und Wirklung (pp. 484-507). Wien: Hölder-Pichler-Tempsky. 